\title{
CGmCGCG is a versatile substrate with which to evaluate Tet protein activity.
}

\author{
$\operatorname{AUTHOR}(\mathrm{S}):$
}

Kizaki, Seiichiro; Sugiyama, Hiroshi

\section{CITATION:}

Kizaki, Seiichiro ... [et al]. CGmCGCG is a versatile substrate with which to evaluate Tet protein activity.. Organic \& biomolecular chemistry 2014, 12(1): 104-107

\section{ISSUE DATE:}

2014-01-07

URL:

http://hdl.handle.net/2433/193040

\section{RIGHT:}

CThe Royal Society of Chemistry 2014; This is not the published version. Please cite only the published version.; この論文は出版社版で ありません。引用の際には出版社版をご確認ご利用ください。 


\title{
CGmCGCG is a versatile substrate with which to evaluate Tet protein activity
}

\author{
Seiichiro Kizaki ${ }^{a}$ and Hiroshi Sugiyama ${ }^{* a, b}$ \\ Received (in $X X X, X X X)$ Xth $X X X X X X X X X 20 X X$, Accepted Xth $X X X X X X X X X 20 X X$ \\ ${ }_{5}$ DOI: 10.1039/b000000x
}

Tet family proteins have the ability to convert 5methylcytosine (mC) to 5-hydroxymethylcytosine, further to 5-formylcytosine and 5-carboxycytosine. We found that CGmCGCG can be the substrate of Tet protein, and observed ${ }_{10}$ iterative oxidation of $\mathbf{m C}$ by HPLC analysis. We also demonstrated that Tet protein favours single-stranded DNA over double-stranded DNA.

\section{Introduction}

Since discovery of the ability of Tet (ten-eleven-translocation) 15 protein to convert 5-methylcytosine (mC) to 5hydroxymethylcytosine (hmC) in 2009, ${ }^{1}$ Tet family proteins have attracted a great deal of attention because of their postulated involvement in the active demethylation pathway. ${ }^{2,3}$ In 2011, it was found that Tet proteins can oxidize hmC further to 520 formylcytosine (fC) and 5-carboxycytosine (caC). ${ }^{4,5}$ Many methods to detect hmC, $\mathrm{fC}$ and $\mathrm{caC}$ in genomic DNA have been developed, ${ }^{6-10}$ and all of these oxidized derivatives of $\mathrm{mC}$ are known to exist in mammalian tissues .,4,11-13 $^{-13}$

To evaluate the ability of Tet proteins to oxidize mC, 20-mer or 25 longer DNAs containing $\mathrm{mC}$ were incubated with Tet protein followed by enzymatic digestion, and TLC, mass spectroscopy or liquid chromatography analysis. ${ }^{1,4,5,14}$ However, these methods require many steps and are time-consuming. In this study, we present a simple and versatile method for assessment of iterative 30 oxidation of $\mathrm{mC}$ by Tet protein.

\section{RESULTS AND DISCUSSION}

First, 3- to 6-mer short DNAs containing mC were synthesized using phosphoramidite chemistry. After purification, each DNA was incubated with mTet 1 protein at $37^{\circ} \mathrm{C}$ for 1 hour, and then 35 the reaction mixture was directly analyzed by reversed-phase HPLC. The percentage of conversion was calculated from the peak area of $\mathrm{mC}$-containing material and hmC-containing product (Fig. 1). Identification of hmC-containing product was conducted by HPLC analysis following enzymatic digestion. Additionally, 40 the reactivity of 20-mer DNAs $^{4}$ was also checked by HPLC following enzymatic digestion of the product (Fig. 1 and Fig. S1, ESI $\dagger$ ). The reactivity of short DNAs was much higher than that of 20-mer DNAs. A 6-mer DNA containing mC at a non-CpG site also reacted with mTet1 to form a hmC-containing product. For

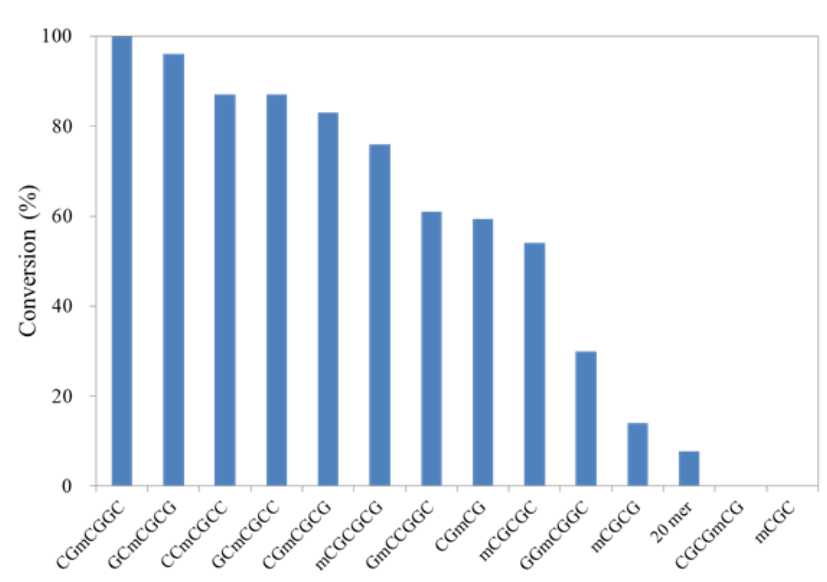

Fig. 1 Reactivity of various DNAs with mTet1 protein. $55.4 \mu \mathrm{M}$ of DNA and $729 \mathrm{nM}$ mTet1 protein were incubated at $37^{\circ} \mathrm{C}$ for 1 hour.

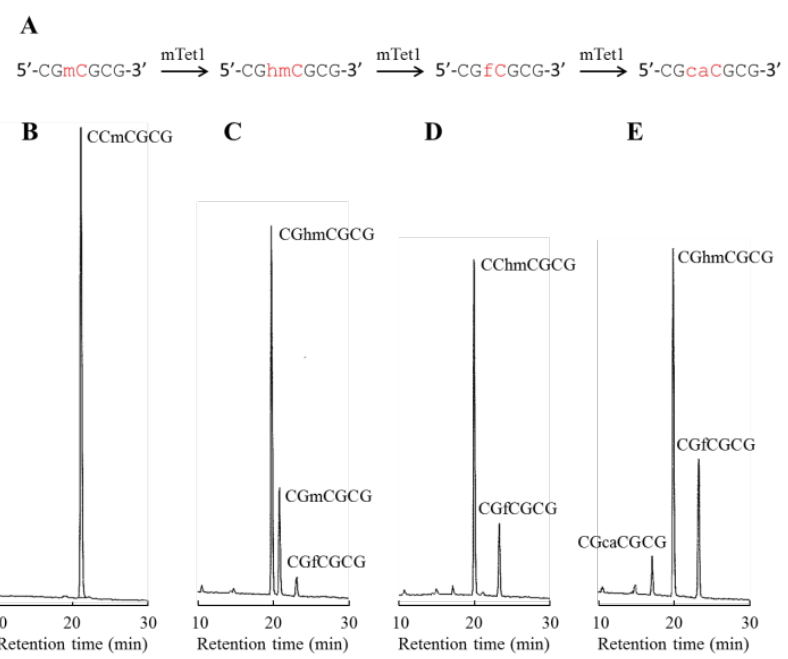

Fig. 2 (A) Oxidation of CGmCGCG by mTet1 protein to form 50 CGhmCGCG, CGfCGCG and CGcaCGCG. 55.4 $\mu \mathrm{M}$ DNA and $7.29 \mu \mathrm{M}$ mTet1 protein were incubated at $37^{\circ} \mathrm{C}$. Elution was with $50 \mathrm{mM}$ ammonium formate containing $0-9 \%$ acetonitrile in a linear gradient at a flow rate of $1.0 \mathrm{~mL} / \mathrm{min}$ for 30 minutes, at $40{ }^{\circ} \mathrm{C}$. (B) Before incubation, (C) 1 min, (D) 3 min, (E) 5 min.

${ }_{55}$ further analysis of the reactivity of short DNA, CGmCGCG was chosen as a substrate because CGmCGCG and its oxidized derivatives showed clearly distinct peaks on HPLC analysis. 


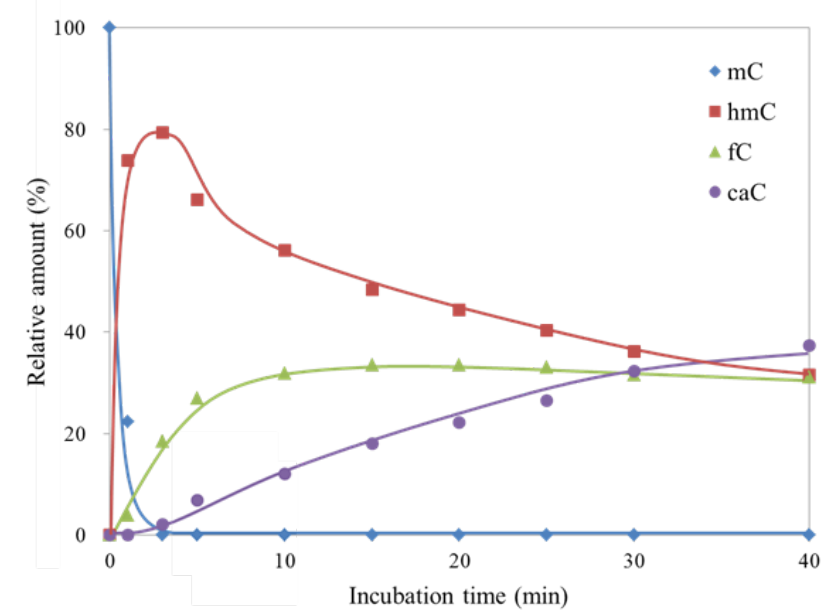

Fig. 3 Kinetic analysis of mTet1 protein. $55.4 \mu \mathrm{M}$ DNA and $7.29 \mu \mathrm{M}$ mTet1 protein were incubated at $37^{\circ} \mathrm{C}$. Relative amount of $\mathrm{mC}$ and its oxidized derivatives at different time points after incubation of mTet1 5 protein with CGmCGCG.

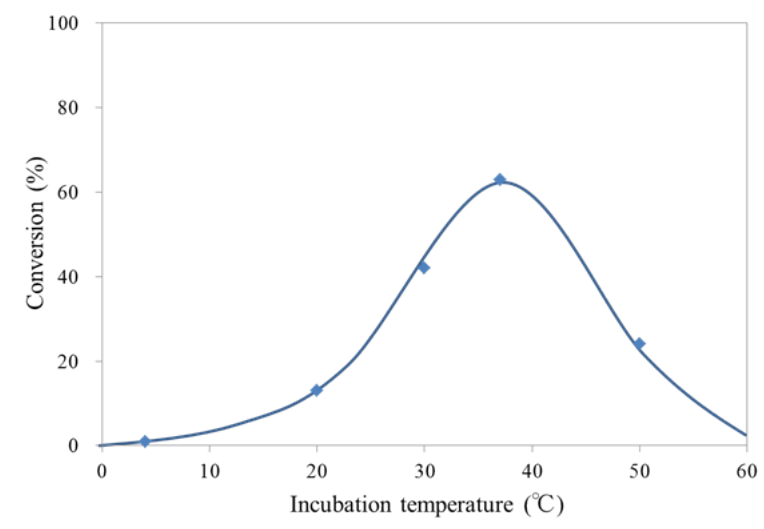

Fig. 4 Temperature-dependency of the reaction of CGmCGCG with mTet1 protein. $55.4 \mu \mathrm{M}$ DNA and $729 \mathrm{nM}$ mTet1 protein were incubated for 1 hour.

10 To investigate dynamic change in the amount of CGmCGCG and its oxidized derivatives, CGmCGCG was incubated with a higher concentration of mTet1 to observe further oxidation of hmC to fC and caC. CGhmCGCG, CGfCGCG, and CGcaCGCG were synthesized using phosphoramidite chemistry and checked 15 by reversed-phase HPLC and ESI-TOF-MS (Fig. S2 and S3, ESI $\dagger$ ). By co-injection of these authentic samples with the reaction mixture of mTet1 and CGmCGCG, each peak was identified in two different solvent systems. After mixing CGmCGCG and mTet1, the reaction was quenched by dilution 20 after an appropriate length of time, and then the reaction mixture was directly analyzed by HPLC (Fig. 2). The oxidation from mC to hmC was rapid and it took only about 3 minutes for CGmCGCG to be completely consumed (Fig. 3). At around 3 minutes, the amount of hmC began to decline and concomitantly 25 the amount of caC began to gradually increase. Finally, the relative amount of each oxidized derivative reached a plateau. This may be the result of the inactivation of the mTet 1 protein described in a previous report. ${ }^{4}$ Additionally, the effect of ATP in the reaction mixture on the oxidation reaction was examined by
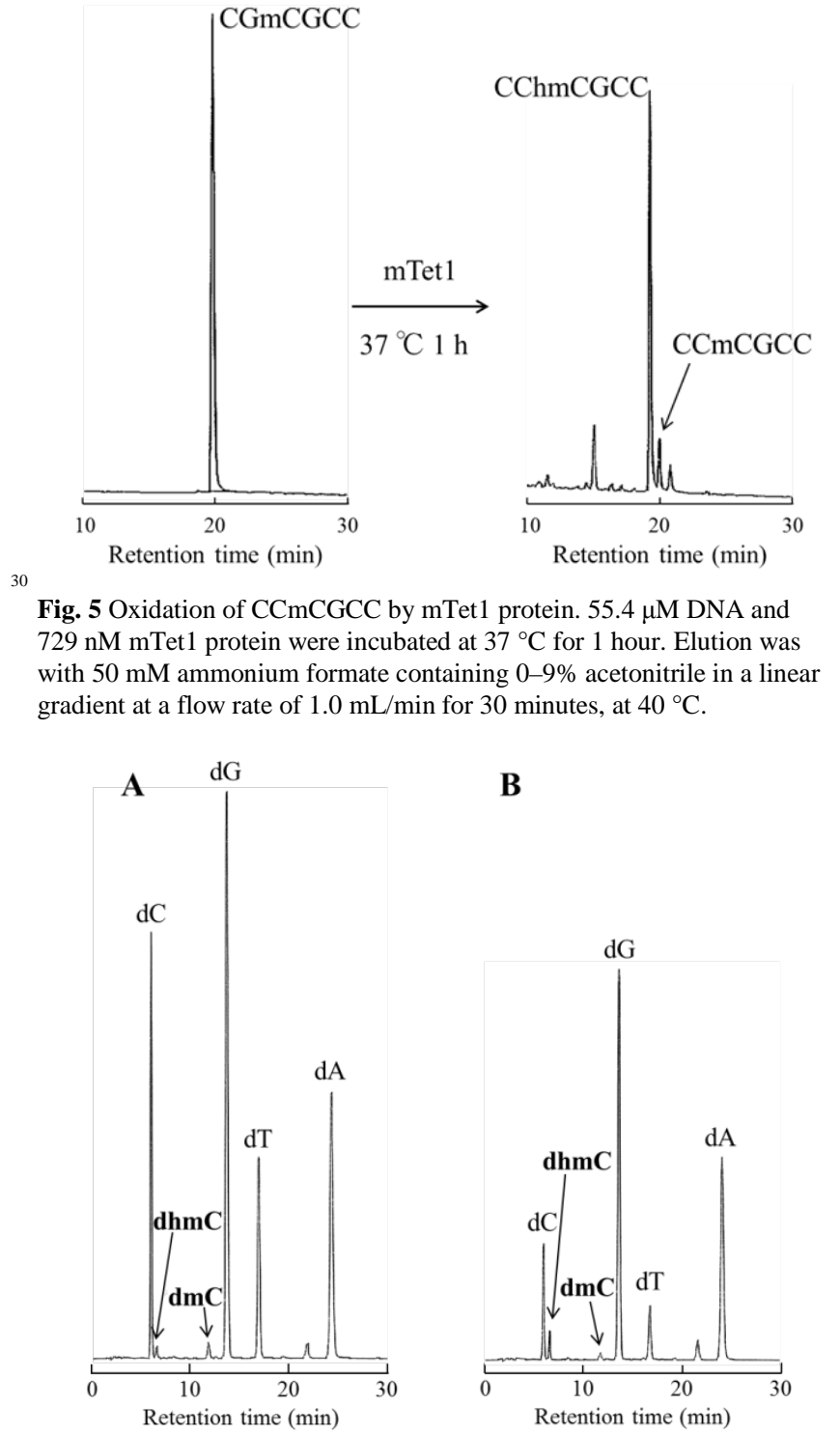

B

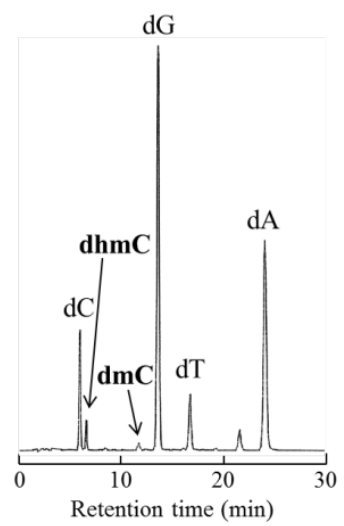

35

Fig. 6 Comparison of the reactivity of 20-mer DNA in the (A) presence or (B) absence of its complementary strand. 16.3 $\mu \mathrm{M}$ DNA and $729 \mathrm{nM}$ mTet1 protein were mixed and incubated at $37^{\circ} \mathrm{C}$ for 1 hour. Elution was with $50 \mathrm{mM}$ ammonium formate containing $0-3 \%$ acetonitrile in a linear 40 gradient at a flow rate of $1.0 \mathrm{~mL} / \mathrm{min}$ for $30 \mathrm{~min}$, at $40{ }^{\circ} \mathrm{C}$.

using CGmCGCG as a substrate (Fig. S4, ESI $\dagger$ ). In the absence of ATP, the conversion efficiency from $\mathrm{mC}$ to hmC markedly decreased. This finding clearly shows that the activity of Tet protein is greatly regulated by ATP as described in a previous 45 report. $^{5}$

To determine the temperature dependency of the oxidation reaction of $\mathrm{mC}$ to $\mathrm{hmC}$ by mTet1 protein, CGmCGCG was incubated with mTet1 protein for 1 hour at various temperatures (Fig. 4). The optimum temperature for the oxidation reaction was 50 around $37{ }^{\circ} \mathrm{C}$. To our surprise, the reaction occurred even at $50{ }^{\circ} \mathrm{C}$. At this temperature, almost all CGmCGCG strands are considered to be present as single strand, suggesting that singlestranded DNA can be the substrate of Tet protein. Therefore, the reactivity of single-stranded DNA was investigated subsequently. 55 Non-self-complementary 6-mer DNA, CCmCGCC was 
incubated with mTet1 protein at $37{ }^{\circ} \mathrm{C}$ for 1 hour followed by direct analysis of the reaction mixture by HPLC (Fig. 5). Indeed, CCmCGCC was oxidized to form CChmCGCC, indicating that Tet protein can act on single-stranded DNA.

5 Subsequently, to examine whether Tet protein prefers $\mathrm{mC}$ oxidation in single-stranded or double-stranded DNA, the percentage of the conversion from $\mathrm{mC}$ to hmC was calculated using 20-mer DNA, 5'-GAGCGTGACmCGGAGCTGAAA-3' in the presence or absence of its complementary strand (Fig. 6). The

10 percentage of the conversion was $29 \%$ for double-stranded DNA, and $68 \%$ for single-stranded DNA. Similar experiment using 5'TTTCAGCTCmCGGTCACGCTC-3' showed same preference (Fig. S5, ESI $\dagger$ ). These results suggest that Tet protein has higher activity on single-stranded DNA than double-stranded DNA.

15 In this study, mTet1 active domain was used for all assays. It is not clear whether full length mTet1 and the other members of Tet family proteins show similar activity. However, it was recently reported that the activity of full length mTet1 is higher than that of mTet1 active domain, ${ }^{5}$ and all Tet family proteins possess 20 similar activity. ${ }^{4,5,14}$

\section{Conclusions}

In the present study, we demonstrated that 4 to 6-mer DNAs can be substrates of Tet protein. In particular, 6-mer DNAs were much more reactive than conventional 20-mer DNAs. Although 25 there is a report about the effects of substrate length on AlkB, $\mathrm{ABH} 2$ and $\mathrm{ABH} 3$ proteins, ${ }^{15}$ to our knowledge this is the first study which has shown the effect of substrate length on Tet protein. By using CGmCGCG, it is possible to readily observe the oxidation of $\mathrm{mC}$ to $\mathrm{hmC}, \mathrm{fC}$, and $\mathrm{caC}$. We also showed that 30 Tet protein can oxidize $\mathrm{mC}$ in single-stranded and double stranded DNA.

\section{Experimental}

\section{General}

For the synthesis of 3- to 6-mer short DNAs, N4-benzoyl-5'-O35 (4,4'-dimethoxytrityl)-2'-deoxycytidine-3'-O-[O-(2-cyanoethyl)N,N'-diisopropylphosphoramidite and N2-isobutyryl-5'-O-(4,4'dimethoxytrityl)-2'-deoxyguanosine-3'-O-[O-(2-cyanoethyl)-

N,N'-diisopropylphosphoramidite were purchased from Sigma Aldrich Japan, 5'-dimethoxytrityl-N-benzoyl-5-methyl-2'40 deoxycytidine,3'-[(2-cyanoethyl)-(N,N'-diisopropyl)]-

phosphoramidite, 5'-dimethoxytrityl-N-benzoyl-5-cyanoethoxymethyl-2'-deoxycytidine,3'-[(2-cyanoethyl)-(N,N'-diisopropyl)]phosphoramidite, 5'-dimethoxytrityl-N-acetyl-5-(1,2-diacetyloxyethyl)-2'-deoxycytidine,3'-[(2-cyanoethyl)-(N,N'-diisopropyl)]-

45 phosphoramidite and 5'-dimethoxytrityl-N-benzoyl-5ethylcarboxy-2'-deoxycytidine,3'-[(2-cyanoethyl)-(N,N'-

diisopropyl)]-phosphoramidite were purchased from Glen Research. Short DNAs were synthesized on 3400 DNA synthesizer (Applied Biosystems). After purification with high50 performance liquid chromatography (HPLC) system equipped with reversed-phase ODS column CHEMCOBOND 5-ODS-H (Chemco Scientific), synthesized short DNAs were checked by HPLC and ESI-TOF-MS Bruker BioTOF II (Bruker Daltonics). DNA concentrations were determined by using Nano drop ND${ }_{55} 1000$ (Thermo Scientific) $\left(50 \mathrm{~cm}^{-1} \mathrm{M}^{-1}\right)$. The sequences of 20 -mer
DNAs are 5'-TTTCAGCTCmCGGTCACGCTC-3', 5'GAGCGTGACmCGGAGCTGAAA-3', 5'TTTCAGCTCCGGTCACGCTC-3' and 5'GAGCGTGACCGGAGCTGAAA-3'. These 20-mer DNAs were 60 purchased from Japan Bio Services (for mC-containing DNA) and Sigma Aldrich Japan.

\section{Tet activity assay}

mTet1 active domain (1367-2039) was purchased from Wisegene, stocked in $20 \mathrm{mM}$ HEPES (pH 7.4), NaCl $50 \mathrm{mM}$, 65 glycerol $50 \%$. DNAs containing mC were incubated with mTet1 protein in $50 \mathrm{mM}$ HEPES ( $\mathrm{pH} 8.0$ ), $100 \mathrm{mM} \mathrm{NaCl}, 2 \mathrm{mM} \mathrm{L}$ ascorbic acid, $1 \mathrm{mM}$ 2-oxoglutarate disodium salt hydrate, 105 $\mu \mathrm{M} \mathrm{Fe}\left(\mathrm{NH}_{4}\right)_{2}\left(\mathrm{SO}_{4}\right)_{2} 6 \mathrm{H}_{2} \mathrm{O}, 1.2 \mathrm{mM}$ ATP and $2.5 \mathrm{mM}$ DTT.

For analysis of the reactivity of 3- to 6-mer DNAs with mTet1 70 protein, $55.4 \mu \mathrm{M}$ DNA and $729 \mathrm{nM}$ mTet1 protein were incubated at $37{ }^{\circ} \mathrm{C}$ for 1 hour (total volume: $25 \mu \mathrm{L}$ ). After incubation, $3 \mu \mathrm{L}$ of the reaction mixture was used for HPLC analysis. For analysis of the reactivity of 20-mer DNAs with mTet1 protein, $55.4 \mu \mathrm{M}$ DNA and $729 \mathrm{nM}$ mTet1 protein were 75 incubated at $37{ }^{\circ} \mathrm{C}$ for 1 hour (total volume: $25 \mu \mathrm{L}$ ). After incubation, the reaction mixture was purified by QIAquick Nucleotide Removal Kit (Qiagen) followed by incubation with nuclease $\mathrm{P}_{1}$ (Wako) and Antarctic Phosphatase (New England Biolabs) at $37{ }^{\circ} \mathrm{C}$ for 4 hours. All of the reaction mixture was 80 used for HPLC analysis. For time-course analysis of the reaction of CGmCGCG with mTet1 protein, $55.4 \mu \mathrm{M}$ DNA and $7.29 \mu \mathrm{M}$ mTet1 protein were incubated at $37^{\circ} \mathrm{C}$ for $1,3,5,10,15,25,30$, 40 minutes (total volume: $25 \mu \mathrm{L}$ ). After incubation, the reaction was quenched by dilution, and $3 \mu \mathrm{L}$ of the reaction mixture was 85 used for HPLC analysis. For temperature-dependency analysis of the reaction of CGmCGCG with mTet1 protein, $55.4 \mu \mathrm{M}$ DNA and $729 \mathrm{nM}$ mTet1 protein were incubated at $4,20,30,37,50{ }^{\circ} \mathrm{C}$ for 1 hour (total volume: $25 \mu \mathrm{L}$ ). After incubation, $3 \mu \mathrm{L}$ of the reaction mixture was used for HPLC analysis. For analysis of the 90 reactivity of $\mathrm{CCmCGCC}$ with mTet1 protein, $55.4 \mu \mathrm{M}$ DNA and $729 \mathrm{nM}$ mTet1 protein were incubated at $37^{\circ} \mathrm{C}$ for 1 hour (total volume: $25 \mu \mathrm{L}$ ). After incubation, $3 \mu \mathrm{L}$ of the reaction mixture was used for HPLC analysis.

For analysis of the reactivity of 20-mer DNA with mTet1 95 protein in the absence or presence of its complementary strand, 16.3 $\mu \mathrm{M}$ DNA and $729 \mathrm{nM}$ mTet1 protein were incubated at $37{ }^{\circ} \mathrm{C}$ for 1 hour (total volume: $50 \mu \mathrm{L}$ ). After incubation, all of the reaction mixture was purified by QIAquick Nucleotide Removal Kit (Qiagen). Purified DNAs were digested with 100 nuclease $\mathrm{P}_{1}$ (Wako) and Antarctic phosphatase (New England Biolabs) at $37{ }^{\circ} \mathrm{C}$ for 4 hours. All of the reaction mixture was used for HPLC analysis. Elution was with $50 \mathrm{mM}$ ammonium formate containing $0-3 \%$ acetonitrile in a linear gradient at a flow rate of $1.0 \mathrm{~mL} / \mathrm{min}$ for 30 minutes, at $40{ }^{\circ} \mathrm{C}$.

\section{${ }_{105}$ Notes and references}

${ }^{a}$ Department of Chemistry, Graduate School of Science, Kyoto University, Kitashirakawa-Oiwakecho, Sakyo-ku, Kyoto, 606-8502, Japan. Fax: +81 75753 3670; Tel: +81 75753 4002; E-mail: hs@kuchem.kyoto-u.ac.jp

${ }^{b}$ Institute for Integrated Cell-Material Sciences (iCeMS), Kyoto

110 University, Yoshida-ushinomiyacho, Sakyo-ku, Kyoto 606-8501, Japan $\dagger$ Electronic Supplementary Information (ESI) available: Fig. S1-4. See DOI: $10.1039 / \mathrm{b} 000000 \mathrm{x} /$ 
1 M. Tahiliani, K. P. Koh, Y. Shen, W. a Pastor, H. Bandukwala, Y. Brudno, S. Agarwal, L. M. Iyer, D. R. Liu, L. Aravind, and A. Rao, Science, 2009, 324, 930.

52 J. U. Guo, Y. Su, C. Zhong, G. Ming, and H. Song, Cell, 2011, 145, 423.

3 S. C. Wu and Y. Zhang, Nat. Rev. Mol. Cell Biol., 2010, 11, 607.

4 S. Ito, L. Shen, Q. Dai, S. C. Wu, L. B. Collins, J. a Swenberg, C. He, and Y. Zhang, Science, 2011, 333, 1300.

105 Y.-F. He, B.-Z. Li, Z. Li, P. Liu, Y. Wang, Q. Tang, J. Ding, Y. Jia, Z. Chen, L. Li, Y. Sun, X. Li, Q. Dai, C.-X. Song, K. Zhang, C. He, and G.-L. Xu, Science, 2011, 333, 1303.

6 M. Yu, G. C. Hon, K. E. Szulwach, C.-X. Song, L. Zhang, A. Kim, X. Li, Q. Dai, Y. Shen, B. Park, J. Min, P. Jin, B. Ren, and C. He, Cell, 2012, 149, 1368.

7 M. J. Booth, M. R. Branco, G. Ficz, D. Oxley, F. Krueger, W. Reik, and S. Balasubramanian, Science, 2012, 336, 934.

8 P. Schüler and A. K. Miller, Angew. Chem., Int. Ed. Engl., 2012, 51, 10704.

209 C.-X. Song, K. E. Szulwach, Q. Dai, Y. Fu, S.-Q. Mao, L. Lin, C. Street, Y. Li, M. Poidevin, H. Wu, J. Gao, P. Liu, L. Li, G.-L. Xu, P. Jin, and C. He, Cell, 2013, 153, 1.

10 X. Lu, C. Song, K. Szulwach, Z. Wang, P. Weidenbacher, P. Jin, and C. He, J. Am. Chem. Soc., 2013, 135, 9315.

2511 S. Kriaucionis and N. Heintz, Science, 2009, 324, 929.

12 M. Münzel, D. Globisch, T. Brückl, M. Wagner, V. Welzmiller, S. Michalakis, M. Müller, M. Biel, and T. Carell, Angew. Chem., Int. Ed. Engl., 2010, 49, 5375.

13 T. Pfaffeneder, B. Hackner, M. Truß, M. Münzel, M. Müller, C. a.

30 Deiml, C. Hagemeier, and T. Carell, Angew. Chem., Int. Ed. Engl., 2011, 123, 7146.

14 S. Ito, A. C. D’Alessio, O. V Taranova, K. Hong, L. C. Sowers, and Y. Zhang, Nature, 2010, 466, 1129.

15 P. Koivisto, T. Duncan, T. Lindahl, B. Sedgwick, J. Biol. Chem., 2003, 278, 44348. 


\section{SUPPLEMENTARY INFORMATION}

A

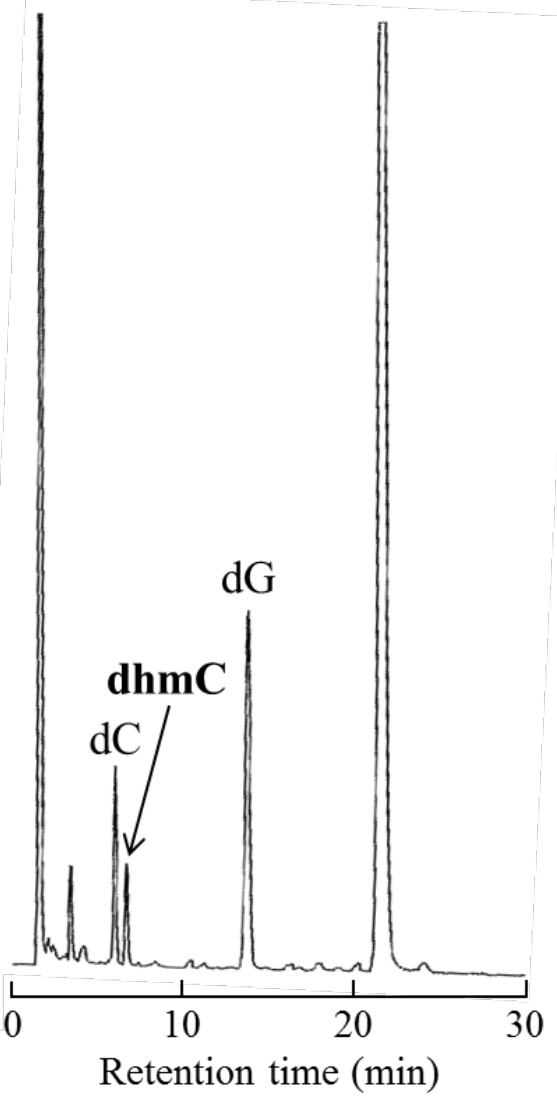

B

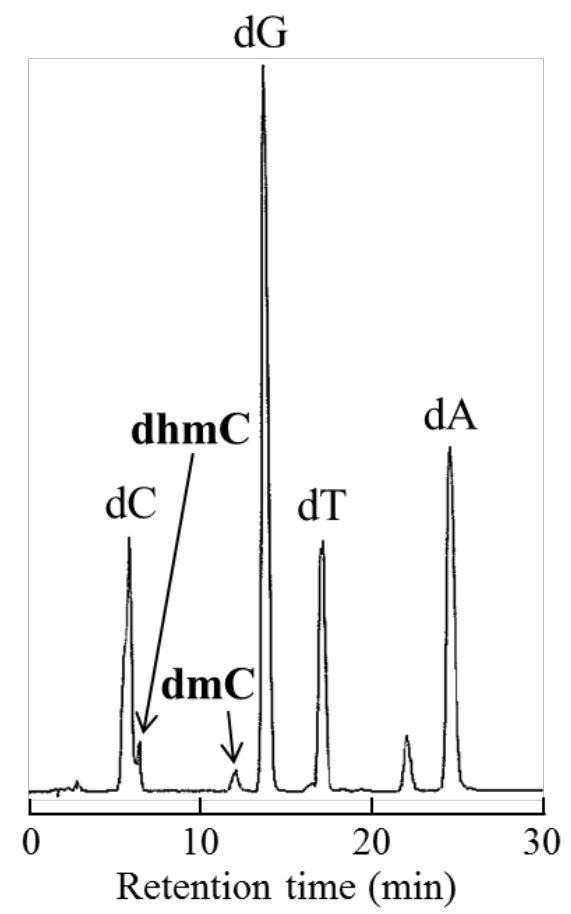

Fig. S1 Comparison of the reactivity between (A) CGmCGCG and (B) 20-mer DNAs. 16.3 $\mu \mathrm{M}$ DNA and $729 \mathrm{nM}$ mTet1 protein were incubated at $37^{\circ} \mathrm{C}$ for 1 hour (total volume: $50 \mu \mathrm{L}$ ). After incubation, half of the reaction mixture was purified by (A) illustra Micro Spin G-25 Columns (GE Healthcare Life Sciences) or (B) QIAquick Nucleotide Removal Kit (Qiagen). Purified DNAs were digested with nuclease $\mathrm{P}_{1}$ (Wako) and Antarctic phosphatase (New England Biolabs) at $37^{\circ} \mathrm{C}$ for 4 hours. All of the reaction mixture was used for HPLC analysis. Elution was with $50 \mathrm{mM}$ ammonium formate containing $0-3 \%$ acetonitrile in a linear gradient at a flow rate of $1.0 \mathrm{~mL} / \mathrm{min}$ for 30 minutes, at $40{ }^{\circ} \mathrm{C}$. 
A

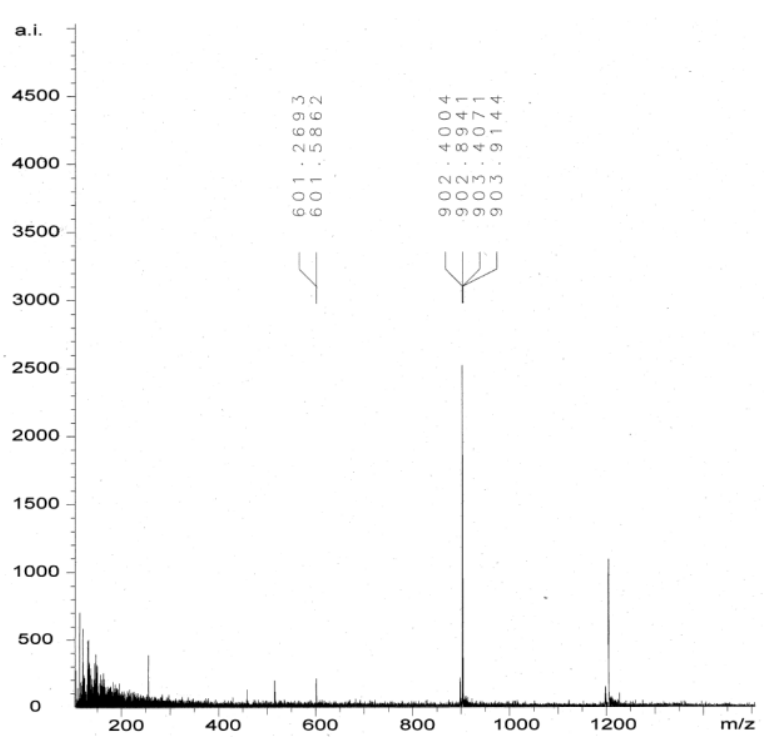

C

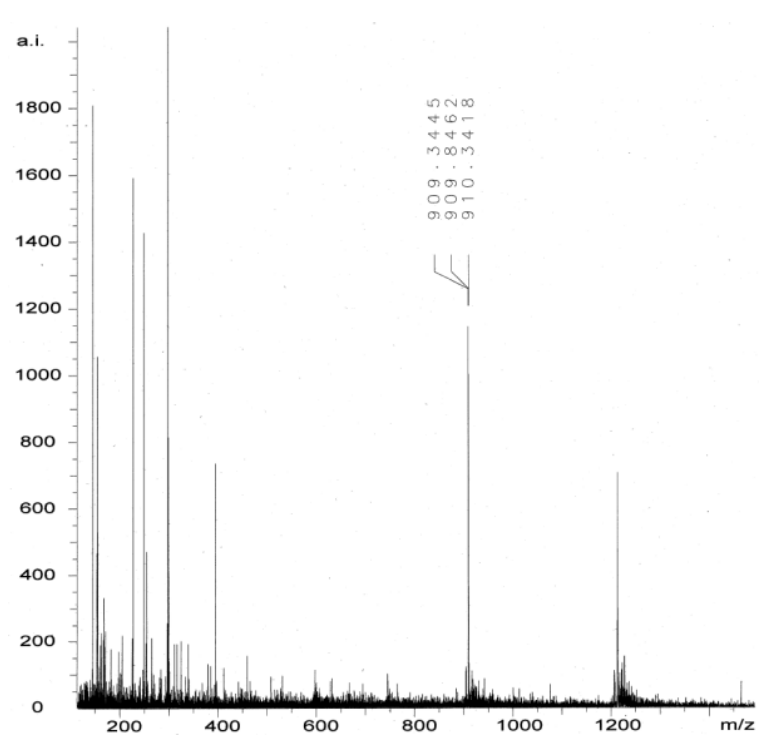

B

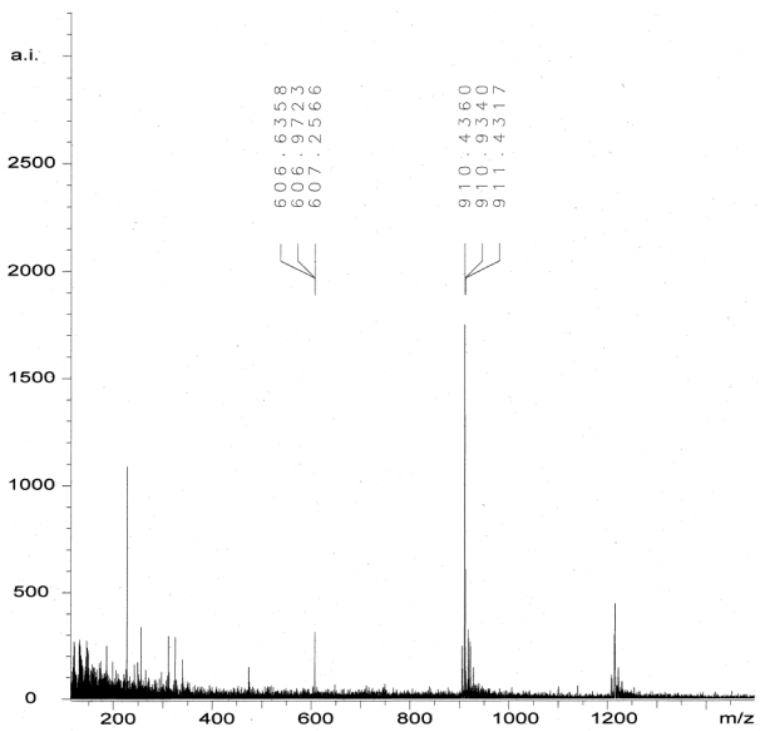

D

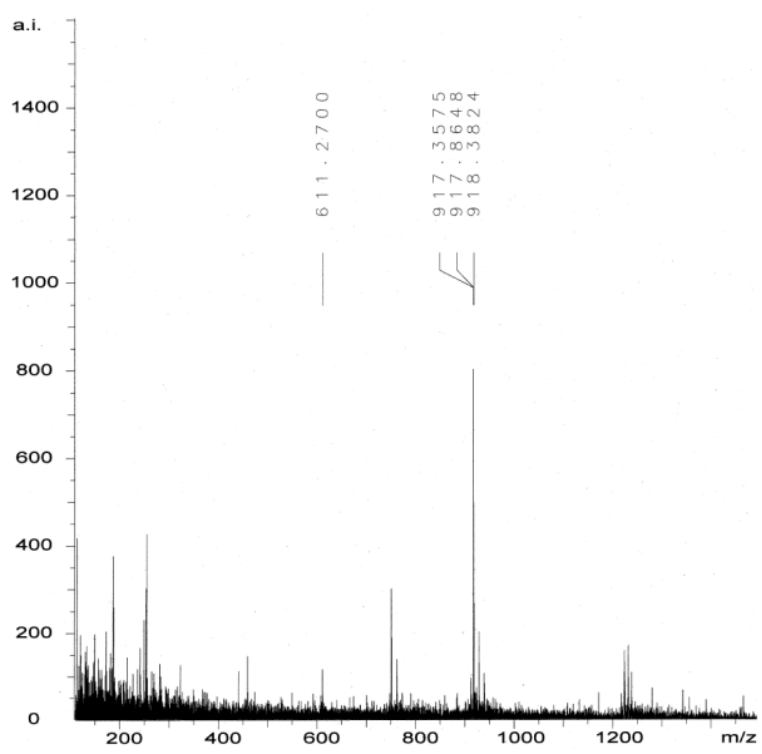

Fig. S2 ESI-TOF-MS analysis of synthesized (A) CGmCGCG, (B) CGhmCGCG, (C) CGfCGCG and (D) CGcaCGCG. Calculated and found m/z value: (A) 902.18 and 902.40, (B) 910.18 and 910.44, (C) 909.17 and 909.34, (D) 917.17 and 917.36 


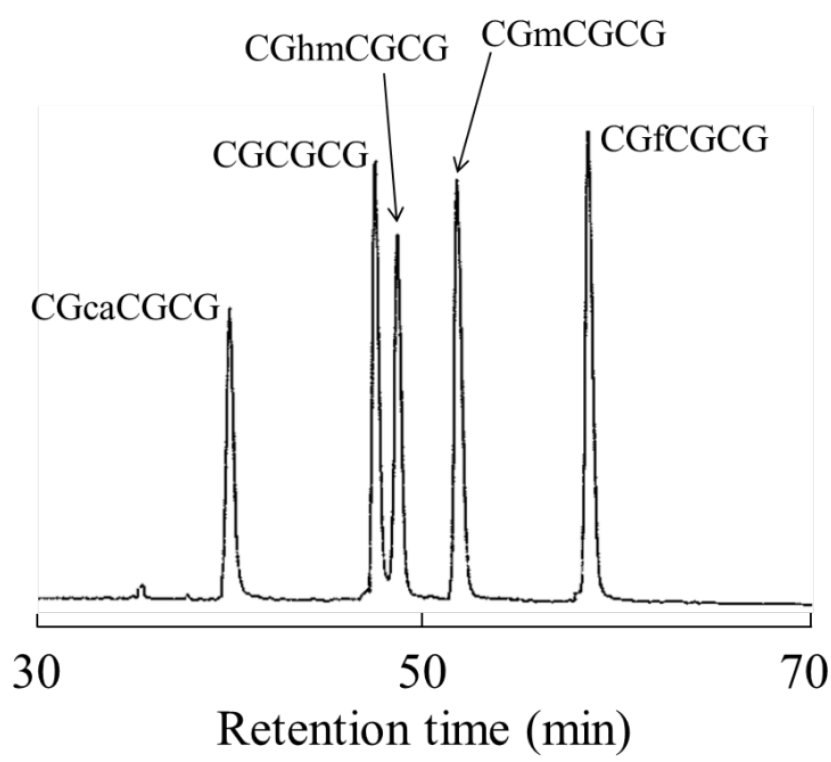

Fig. S3 HPLC analysis of synthesized CGCGCG, CGmCGCG, CGhmCGCG, CGfCGCG and CGcaCGCG. Elution was with $50 \mathrm{mM}$ ammonium formate containing $0-7 \%$ acetonitrile in a linear gradient at a flow rate of $1.0 \mathrm{~mL} / \mathrm{min}$ for 70 minutes, at $40^{\circ} \mathrm{C}$. 
A

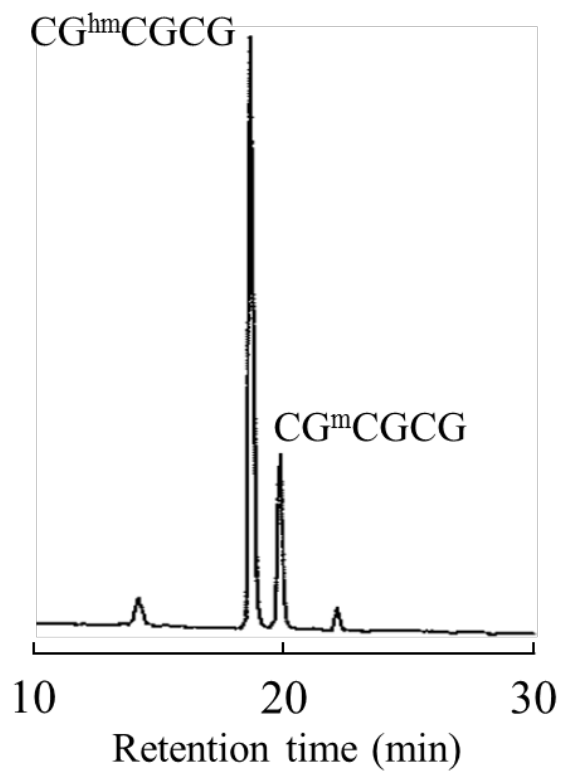

B

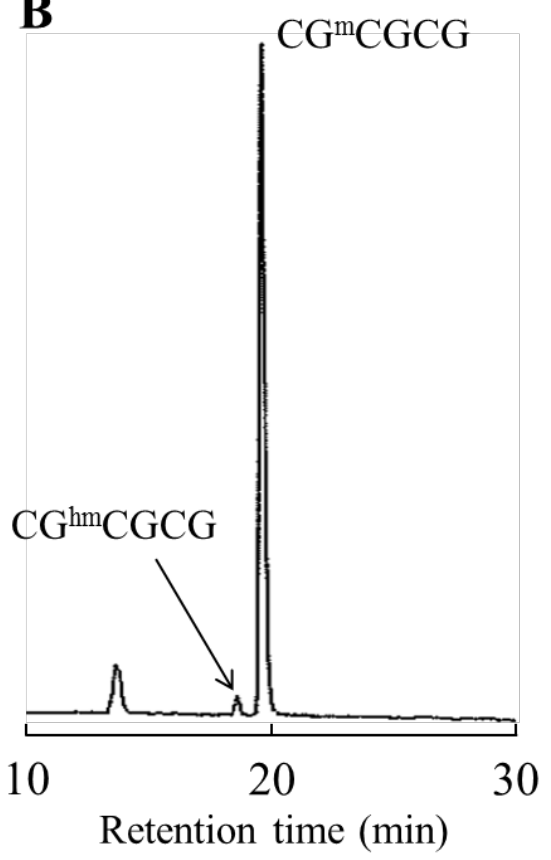

Fig. S4 Oxidation of CGmCGCG by mTet1 protein in the (A) presence or (B) absence of ATP. $55.4 \mu \mathrm{M}$ of DNA and $729 \mathrm{nM}$ mTet1 protein were incubated at $37^{\circ} \mathrm{C}$ for 1 hour (total volume: 50 $\mu \mathrm{L})$. After incubation, $3 \mu \mathrm{L}$ of the reaction mixture was used for HPLC analysis. Elution was with $50 \mathrm{mM}$ ammonium formate containing 0-9\% acetonitrile in a linear gradient at a flow rate of 1.0 $\mathrm{mL} / \mathrm{min}$ for 30 minutes, at $40^{\circ} \mathrm{C}$. 


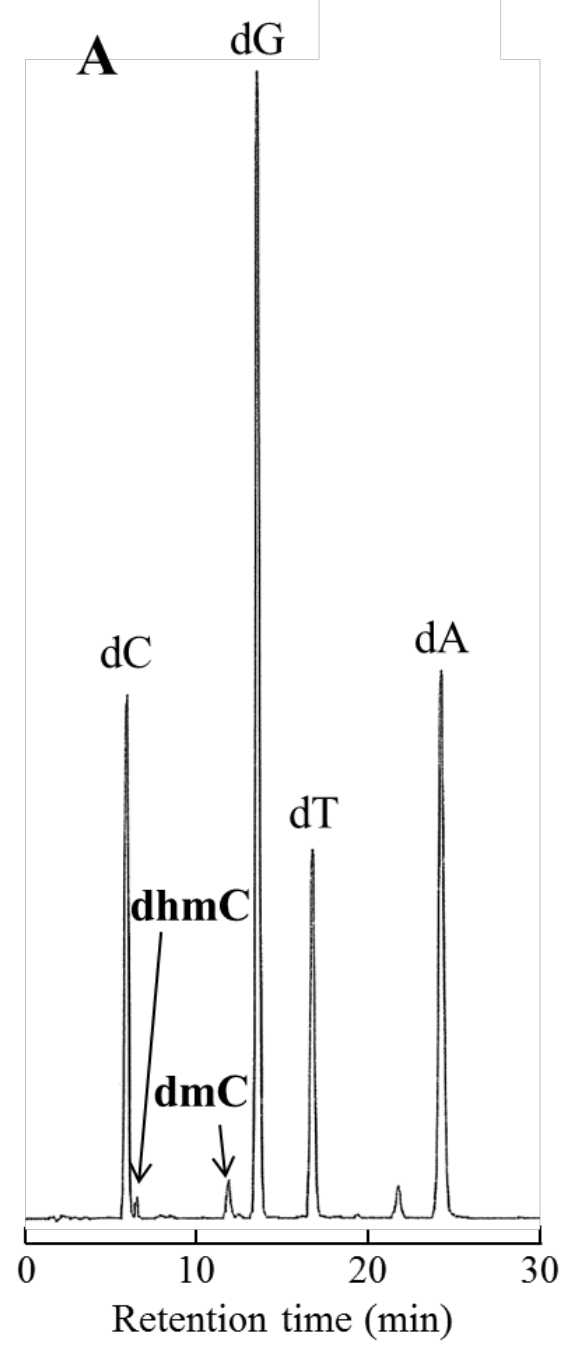

\section{B}

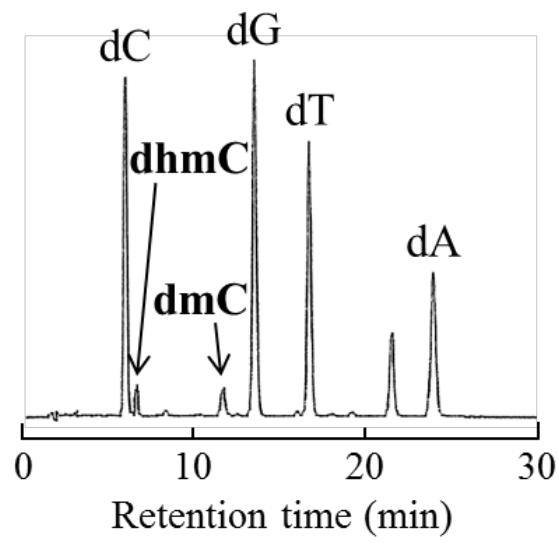

Fig. $\mathbf{S 5}$ Comparison of the reactivity of 20-mer DNA, 5'-TTTCAGCTCmCGGTCACGCTC-3' in the (A) presence or (B) absence of its complementary strand. $16.3 \mu \mathrm{M}$ DNA and $729 \mathrm{nM}$ mTet1 protein were mixed and incubated at $37^{\circ} \mathrm{C}$ for 1 hour (total volume: $50 \mu \mathrm{L}$ ). After incubation, all of the reaction mixture was purified by QIAquick Nucleotide Removal Kit (Qiagen). Purified DNAS were digested with nuclease $\mathrm{P}_{1}$ (Wako) and Antarctic phosphatase (New England Biolabs) at $37^{\circ} \mathrm{C}$ for 4 hours. All of the reaction mixture was used for HPLC analysis. Elution was with 50 $\mathrm{mM}$ ammonium formate containing $0-3 \%$ acetonitrile in a linear gradient at a flow rate of 1.0 $\mathrm{mL} / \mathrm{min}$ for $30 \mathrm{~min}$, at $40{ }^{\circ} \mathrm{C}$. Conversion was $27 \%$ and $41 \%$, respectively. 